\title{
From bad to worse? The fate of Swedish in America [1]
}

\section{Av Staffan Klintborg, universitetsadjunkt i engelska}

\author{
Länk till presentation av Staffan Klintborg
}

Right! Well, you know, my field, I mean what I'm sort of going to talk about, anyway, is BAD LANGUAGE. OK, I know, this is supposed to be BAD! We have all got irritated when listening to people using too much of these. Not to speak of how irritated people usually are when you mix in these discourse markers (Schiffrin 1987), pragmatic particles (Östman 1995), alternatively pragmatic markers (Brinton 1996) or discourse particles (Aijmer forthcoming) or if you prefer fillers, linkers, tags and flags (Klintborg 1996), when you mix these whatchammacallit from Language A in speech in Language B.

Even at the beginning of this century American Swedish speech, which is my field of research, by the way, was criticized for its use of all right and well. It was said to be untranslatable and the frequency of yes and no was seen as a symptom of carelessness about language (Berger 1912:19). It wasn't really until the 1960s that a more balanced scholarly view was aired by Hedblom, who assigned this frequent use of and, but and because to new speech-habits.

For my research I listen to tapes in the Emigrant archives in Växjö. They contain interviews with Swedes made in North America in the mid-80s. Most of the interviewees were born around 1900 and emigrated in the 1920s, when they were themselves in their 20s. Practically every speaker shows signs of these 'new speech-habits' - bad or not - a habit also found for instance among Puerto Ricans in New York (Poplack 1980) or Germans in Australia (Clyne 1967).

The items I have chosen to study figure prominently in American Swedish speech. The largest group comprises what Quirk et al (1985:444) call reaction signals and initiators, namely, in order of frequency, no, well and yes. Even more frequent is the reaction signal yeah, but it's difficult to distinguish from Swedish ja. This group also comprises some marginal 'noises' like huh-uh. The second largest group is made up of the connectives and, but, or and because (or cos). Y'know and you see (usually only heard as see) represent the group of hearer-oriented items, and we also find speaker-oriented ones like I mean, I guess and s'pose; hedges, especially kind of, usually pronounced kanda; final tags like or something, and so on.

Following Halliday \& Hasan (1976), Schiffrin (1987) and other pioneers in this field I first looked into the discourse function from a mainly textual perspective. What distinguishes my material from theirs was the fact that my markers are code-switched, i.e. they are phonologically and morphologically non-integrated chunks of English in Swedish speech. Looking for a possible explanation for all these noes and sees and coses I found Clyne's (1967) triggering model, which claims that words overlapping the languages may cause the speaker to forget which language was just used and therefore make a switch into the other. An example from my material reads:

1. de va den äldste pojken - han va i New York - and he was gonna have some kind of - conference or whatever

('it was the oldest boy - he was in New York')[2]

Then the English name 'triggers' a continuation in the same language. 
Usually the switch takes place after the trigger-word, consequential triggering, as Clyne calls it. Not quite so common is anticipational triggering, where the switch begins earlier, in anticipation of the trigger-word. Words like and, between and or, Clyne concludes (1967:89), are especially vulnerable to triggering, since they are often 'sandwiched' between names.

In order to find out whether Clyne's model can be applied on the code-switching of markers in American Swedish, I made a sample of ten speakers and registered every single and, but, or and cos and the language environment in which they occurred (See Table 1). Thus, I obtained frames like E+AND+S, meaning that a particular token of and is preceded by an English and followed by a Swedish word, or S+AND+E meaning the reverse.

The first observation that can be made is that but and or more often trigger a switch into English than in the other direction. As for and, the most frequently switched conjunction, it's followed by an equal number of switches both ways. What is the more striking, however, is that the $\mathrm{S}+\mathrm{CONJ}+\mathrm{S}$ frame far outnumbers the other two types. The same pattern was found for $y^{\prime}$ know and see, and, overwhelmingly so for yes, no and well (Tables $\underline{2}$ and $\underline{3})$.

To sum up: switches into the language of the marker is more common than a switch in the reverse direction, but the great majority of switched English markers stand alone in an allSwedish frame. For these, Clyne's triggering hypothesis doesn't provide the explanation. On the contrary, the results support Hasselmo (1970:187), who came to the conclusion that switches like these are independent of "other E [=English] stretches in the same discourse".

How bad is it then that these markers figure so prominently among Swedish emigrants? If you think, as prescriptive non-linguists often do, that code-switching in itself is bad, then of course the language of some of these old people is really bad. However, as descriptive linguists, we are aware that code-switching is not necessarily a symptom of language badly acquired or badly treated, but that it can be a very conscious strategy. We ourselves can be quite heavy switchers sometimes. Nevertheless, most of us would probably admit that when $y^{\prime} k n o w$ or $v a$ is woven into every utterance, it doesn't suggest a strategic use of language. With individuals doing that, these markers actually seem to have become second nature.

Still, I don't think those of you whose mother tongue is English sprinkle it with naj or jeg mener or förståru or typ, unless you do it for fun. Swedish Swedes and Danish Danes don't walk around either punctuating their utterances with well or I guess. How do we then explain that these old Swedes, whose lexicon and grammar may still be well preserved, so whole-heartedly adopt these little American words?

Of course, it's not usually a question of them forgetting och, eller, nej, jaså and other common Swedish words. Surely, the appearance of the English equivalents is a performance, not a competence, phenomenon. Not a nonce-performance phenomenon, but something that has become deeply ingrained after about sixty years' residence in the new country: perhaps not even second, but first nature. We may call this process automaticity or routinization, but it's hard to find an overall explanation why some people are more prone to use routines than others. It certainly matters how often they have gone back to or received visitors from Sweden and whether they are married to another Swede or not. For me this 'rusty Swedish' is a symptom of a transient language: a symptom of language attrition and impending language death.

This was one approach - a primarily textual approach to these 'small words'. A further step is to go beyond the purely textual function to what is pragmatics in a wider sense. Fernandez (1994:5) says about une PEN, her short form for the French term particule énonciative: "Une PEN doit ... ancrer les messages du locuteur dans ses attitudes (/ [ou] sentiments) de façon indirecte ou implicite." (A 'PEN' ought to anchor the speaker's messages in his attitudes (/[or] sentiments) indirectly or implicitly.) A parallel is Östman's (1995:100-101) concept of implicit anchoring. Östman sees communication as taking place 
simultaneously on two levels: the explicit propositional level, and the implicit level, where our attitudes and opinions are anchored to the context at large. The pragmatic particles, he continues, are the 'windows' par excellence in the explicit surface level, "through which one can see ... what is being communicated on the attitudinal level 'beneath' ". In other words, these 'window' particles in their affective and cultural-coherence functions signal, among other things, the attitudes and the involvement of the speaker.

These ideas have striking similarities with the theory of contextualization, introduced by Gumperz (1982) and developed by Auer (1984). Contextualization is what is created, according to this theory, in the course of conversation and its aim is to make propositions interpretable. Among the contextualization strategies mentioned by Auer are prosodic cues, gestural and kinetic cues, such as eye contact and change of posture, and also, he adds, code-switching. Now, if code-switches are one contextual or interactional cue, and pragmatic particles another interactional cue, what about pragmatic particles that are codeswitched?

With that question at the back of our heads, let me present a few examples.

2) vi var i Glömminge you know

The speaker recalling an experience from his childhood introduces it by identifying the Swedish setting. By means of a hearer-oriented marker, he checks whether the interviewer is familiar with the place. But why doesn't he say du vet, or förståru? The interviewer is Swedish and Swedish is the basic language of the interview. Triggering can hardly be the cause of the switch into English, since the place-name is Swedish. It's true that Clyne also has a special category called situation triggering: if the context or situation is strongly reminiscent of the other culture, a language switch may take place, as when I, being a native of Gotland, hear the name of my island and immediately begin speaking in a Gotland accent. But this situation should conjure up Swedish, not English.

Let me try to assume the role of the speaker: Along comes this other Swede; he wants to know everything about my childhood in Sweden. How wonderful to get an opportunity to speak Swedish! That doesn't happen much nowadays. All right, let's show him that I haven't forgotten how to 'språka svenska'! Still, I must admit, it isn't easy to retrieve all these words for tools and processes that I haven't heard or used for ages. Honestly, these nouns and verbs - require so much energy that I can't be bothered with the 'small words'. But, what the heck! I know that this Swede has also been over here for many years, even if of course he hasn't been around as long as me. The language we both use most of the time is English. Aren't we really playing a kind of game, sitting round this tape-recorder trying to speak just Swedish?

Talking about old times, a lot of names crop up:

\section{3) Olsson an Karlsson an Larsson an Jansson}

All Swedish names, but the glue is English. Maybe all these people also came over in the 20s, so we should really perceive their names as Carlson and Larson and Johnson? But let us look for some Swede talking about his brothers and sisters. Here is one:

4) de va Selma - Agda and Alma and Tor and Ivar.

Words associated with kinship are supposed to be among those that last the longest from your first language. But the windows between the propositional facts gives us a glimpse that these names are viewed from the perspective of an old man in his new, adopted country. The new setting has taken over from the old and the new language is the language used for interaction.

If we return briefly to the first example, "vi var i Glömminge you know", we find that the particle is short, is in a final position and forms its own tone-unit, in other words it fulfils 
several of those criteria that are usually set up for pragmatic particles but also for codeswitches. In the roll-calls of names we just heard, and can be said to substitute for a pause, another expected switch slot. There are, however, other slots, where code-switching is supposed not to be possible, because of certain constraints we can read about in the literature on bilingualism. One such constraint rules out switching inside an idiom. Therefore it's surprising to find English particles inside Swedish idioms:

5) [vi]? fick lite arbete här and där.

If our definition of an idiom is wide enough to include other collocations, we may ask ourselves what causes the internal switching that some of them contain? Present company may, for example, find it strange to make a distinction like the following:

6) di va me danska(r?) å norska an - an svenska

We may not think of ourselves as one Scandinavian idiom, but perhaps as an extended family. But there seems to be a split in this family, because although the Danes and the Norwegians run smoothly together, the Swedes are marked off both by a hesitation pause and by a code-switch.

We have already heard that not even those nearest of kin are immune to switching. What about this then?:

7) we met - hennes mamma an pappa

Hennes mamma an pappa, not hennes mamma å pappa. Both phrases can of course be rattled off easily, so easily indeed that no one will hear the difference, except the linguist who can rewind his tape-recorder to hear what is really said:

8) han är åttifem å åttisex år gammal

Curious: 85 + 86 makes 171...? But, of course, the conjunction isn't Swedish och, usually pronounced $a$, but English or. We can conclude, then, that switched particles appear not only in clauses, but also in phrases, and they can even worm their way right inside Swedish idioms.

But they don't always slip by as unnoticed as the $y^{\prime}$ knows and the ands and the ors. Not if they appear initially, are strongly emphasized, and even repeated:

9) [hyrde dom rum till arbetare] oh no no no [de gjorde dom inte]

It's impossible to know precisely what lies behind this string of negative particles, but certainly it goes beyond the strictly propositional. On the interactional level, maybe the speaker expresses his surprise that the interviewer didn't know that these people, whoever dom were, didn't let rooms to workers. On a deeper level, this emphatic string might even reveal something of the speaker's attitudes to workers or to letting rooms to such people. Of course, we can't tell from just this string. But I think it's perfectly clear that the example shows the speaker's involvement, and it's the switch that makes this involvement shine through.

On another tape we hear the interviewer expressing his surprise that his interviewee wasn't more hågad ('keen') to stay in Sweden and follow in his father's footsteps by taking over jordbruket ('the farming'):

10) [men du var inte nå vidare hågad på jordbruket då] no jordbruk no - no no no - I never wanna touch it

The subject is obviously such a delicate matter that the speaker completely leaves off the language the interview started in, and utters his genuine feelings in the language he 
normally uses not just to conduct business, but to express his attitudes, his emotions, and his deepest convictions. And that language is English, not Swedish!

People who are carried away by their emotions, often express themselves by a whole string of particles: oh no - well, oh ja you know, oh ja - well - no, oh yes sure ja, ja well see then, no - but then - see, no no uhhuh ... All these examples were taken from Swedish contexts, and they are all-English strings, with a reservation for those containing ja. However, there are strings mixing both languages: ja - nej - ja - no, de va de väl I guess, ja du see. In no $d a-n o$, the word sandwiched between the two negations clearly echoes Swedish nej $d a$ or jo da. There is no English word that can be confused with $d a$. But it isn't always easy to identify which is which. See/se and so/så, for example, are near homophones. Where is the switch-point then of and so vidare? And what do we make of well not vidare? Is it a truncated version of Swedish inte nåt vidare, which roughly means 'not very much' or 'not very well', with nåt being a merger of the English negation and the Swedish indefinite pronoun? Confusion now hath made his masterpiece!

In the beginning of this paper I more or less refuted Clyne's hypothesis that a trigger-word can result in a switched particle, e.g. a conjunction. But Clyne also says that conjunctions themselves can sometimes act as triggers. This might help to explain some types of codeswitching which are otherwise odd, for instance:

11) because I skulle gå å hälsa på, ('I was going to visit'),

or:

12) I guess he sa så anyway ('I guess he said so anyway').

Personal pronouns, because of their very nature, are most unlikely cases of switching, unless they form part of a larger chunk. For cases like these single $I$ and he, the idea of a spill-over from the conjunction itself is perhaps the explanation nearest at hand. If then a conjunction can trigger a sequel in English, what about reaction signals? Here is an emigrant reminiscing about how bewildered he was when he had just arrived and was desperately trying to understand the language he heard around him. This bewilderment is almost metaphorically expressed in his answer to the question of how much English he understood on arrival:

13) no inte mycke - no inte mycke - no very - mycke lite

Intensifiers are rarely switched, but is it only just another word triggered by the preceding negation? Or is this another case of heightened involvement in close vicinity to a pragmatic marker?

This may bring to mind a point made early on, namely that instead of drawing a sharp dividing-line between code-switching and transfer, the two aspects of language alternation should be looked upon as a continuum. One argument in favour of this view is that transfer often appears close to pure switches. When, for instance, one of my speakers answers the question whether there were a lot of people around, he says:

14) ja ja - ja de va - oh yes

The reinforcing phrase ja de va follows the word order of English yes it was -very unlike standard Swedish, which requires an extra det: ja de va de. What we have got is thus syntactic transfer in close proximity to, or even embedded in, a code-switch, if we interpret ja as yeah. To point out that a transfer follows close upon a switch isn't tantamount to saying that it's triggered by it. But it's tempting to see a connection. When the interviewer asks: Var du me i godtemplarna ('had you joined the Good Templars')?, this is the answer he receives:

15) ja but ja ja didnt tillhöra godtemplarna because ja var för ung 
A true equivocation! He admits to joining the Good Templars but denies belonging to them, because of his youth. This is, admittedly, my only example so far of the do-periphrasis applied on a Swedish verb. What inhibited attitudes or emotions does this bespeak? What the hammer? what the chain? In what furnace was thy brain? Is it simply bad language?

How large a role does the interviewer play?. The interview in itself is of course a speech situation that in many respects differs from ordinary conversation. The set-up is more formal, and the interviewer naturally takes the lead. Since he, or she, chooses the questions, it can't be ruled out that the way a question is framed may influence the answer. As far as the bilingual situation is concerned, the interviewer usually keeps a neutral stance in that he doesn't comment on the interlocutor's language, but tries to steer the language back into the Swedish channel if it strays too far. Only occasionally does our interviewer break his own rules as in the following comment:

\section{6) [you are mixin English and Swedish]}

The answer he gets is revealing on more than one level:

- well I do - jag hör aldri någon svenska any mera

Language loss is not just a process; it also entails a feeling of being lost. The Last of the Emigrants, where do they stand emotionally? Culturally, with their Midsummer rites and Christmas dinners they show their allegiance to the old country, even though the 'Swedish' smorgasbord may include spaghetti with marshmallows. Languagewise, they pay homage to their origin by endeavoring to 'speak Swede', and some of them speak remarkably 'good'. But does their innermost agree with what they profess?

One clue to where their affiliation really lies may be what I call 'flags', metalinguistic phrases. When my Swedes in America break off their Swedish speech with a flag in English, that in itself is no different from the use of a linker or filler or tag. But we must also listen to the words of the flag: what do they call it now again, oh what do you say. The choice of pronoun suggests distancing: they are the other Swedes, somewhere far away in time and space, and you could of course be the interviewer, but it's much more likely to be generic you, as in this sausage word query:

17) I dont know what you kallar den s korven - isterband

The reason why we other speakers of the Swedish language are referred to in the third or the second person may be that the first person is reserved for the new language:

18) what do we - på engelskan -

The speaker continues: well anyhow vi skulle inte använda de i vårt språk ('we wouldn't use it in our language'). What if our language turns out to be English?

It's often maintained that when everything else of the first language has disappeared, counting, praying and dreaming remain. And swearing. Despite that, when one of our gentlemen thinks back of an old Swedish friend of his:

19) han hade fått sin skolning i Augustana å å

he hesitates and bursts out in exasperation:

- what the heck was his name

If you can learn to swear in another language, then you have really proved your capacity to assimilate. With great admiration somebody recalls an American foreman who really got on well with his workers by learning to swear in Swedish: 
20) han kunde - svärja just beautiful på svenska see - oh oh just beautiful

My very last example should sum up beautifully what I have been trying to convey through this paper:

21) what the hell var de di (?) - va fan did they call it in Sweden

If that isn't BAD LANGUAGE what is?

(C) Staffan Klintborg

\section{Tables}

Table 1: Frequency of code-switching involving linkers I: AND, BUT, OR and COS*

Frames: Speakers:

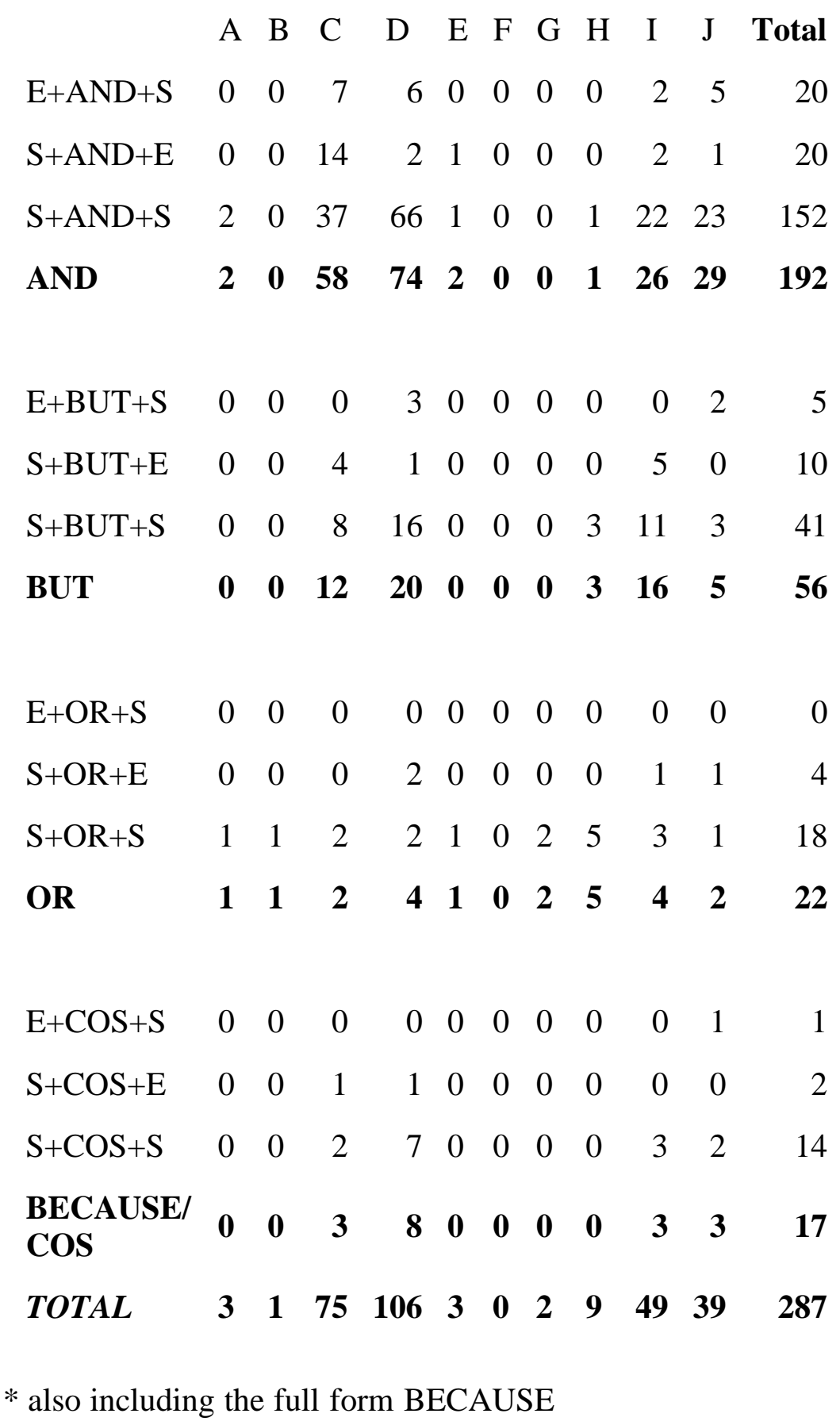


Table 2. Frequency of code-switching involving tags YOU KNOW* and SEE (incl. YOU SEE)

Frames: $\quad$ Speakers:
A

TAGS

\begin{tabular}{|c|c|c|c|c|c|c|c|c|c|c|}
\hline $\mathrm{E}+\mathrm{YK}+\mathrm{S}$ & 0 & 0 & 0 & 2 & 0 & 0 & 0 & 0 & 0 & 1 \\
\hline $\mathrm{S}+\mathrm{YK}+\mathrm{E}$ & 0 & 0 & 1 & 6 & 0 & 0 & 0 & 0 & 0 & 1 \\
\hline $\mathrm{S}+\mathrm{YK}+\mathrm{S}$ & 0 & 0 & 0 & 8 & 0 & 0 & 0 & 0 & 2 & 1 \\
\hline$S+Y K+\varnothing[3]$ & 0 & 0 & 0 & 11 & 0 & 0 & 0 & 1 & 0 & 1 \\
\hline YOU KNOW & $\mathbf{0}$ & $\mathbf{0}$ & 1 & 27 & $\mathbf{0}$ & $\mathbf{0}$ & $\mathbf{0}$ & 1 & 2 & 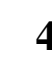 \\
\hline $\mathrm{E}+\mathrm{SEE}+\mathrm{S}$ & 0 & 0 & 0 & 1 & 2 & 0 & 0 & 0 & 0 & 2 \\
\hline $\mathrm{S}+\mathrm{SEE}+\mathrm{E}$ & 0 & 0 & 2 & 4 & 0 & 0 & 0 & 0 & 0 & \\
\hline $\mathrm{S}+\mathrm{SEE}+\mathrm{S}$ & 0 & 0 & 0 & 6 & 5 & 0 & 2 & 2 & 2 & 7 \\
\hline $\mathrm{S}+\mathrm{SEE}+\varnothing$ & 1 & 3 & 0 & 26 & 4 & 0 & 0 & 3 & 2 & 22 \\
\hline $\begin{array}{l}\text { SEE/ } \\
\text { YOU SEE }\end{array}$ & 1 & 3 & 2 & 37 & 11 & $\mathbf{0}$ & 2 & 5 & 4 & 33 \\
\hline
\end{tabular}

* The abbreviation YK is uses in the frames.

Table 3: Frequency of code-switching involving linkers II: YES (incl. OH YES), NO (incl. OH NO) and WELL[4]

Frames: Speakers:

$\begin{array}{lrrrrrrrrrrr} & \text { A } & \text { B } & \text { C } & \text { D } & \text { E } & \text { F } & \text { G } & \text { H } & \text { I } & \text { J } & \text { Total } \\ \text { E+YES+S } & 0 & 0 & 1 & 1 & 0 & 0 & 0 & 0 & 0 & 2 & 4 \\ \text { S+YES+E } & 0 & 0 & 0 & 4 & 0 & 0 & 0 & 0 & 0 & 4 & 8 \\ \text { S+YES+S } & 0 & 0 & 0 & 5 & 17 & 0 & 0 & 2 & 0 & 37 & 61 \\ \text { S+YES+Ø } & 0 & 0 & 0 & 2 & 0 & 0 & 0 & 0 & 0 & 2 & 4 \\ \text { YES } & \mathbf{0} & \mathbf{0} & \mathbf{1} & \mathbf{1 2} & \mathbf{1 7} & \mathbf{0} & \mathbf{0} & \mathbf{2} & \mathbf{0} & \mathbf{4 5} & \mathbf{7 7} \\ & & & & & & & & & & & \\ \text { E+NO+S } & 0 & 0 & 0 & 3 & 0 & 0 & 0 & 0 & 0 & 1 & 4 \\ \text { S+NO+E } & 0 & 0 & 0 & 5 & 4 & 0 & 0 & 0 & 1 & 6 & 19 \\ \text { S+NO+S } & 1 & 0 & 9 & 19 & 59 & 1 & 3 & 2 & 13 & 42 & 149 \\ \text { S+NO+Ø } & 0 & 0 & 0 & 2 & 0 & 0 & 0 & 0 & 0 & 0 & 2 \\ \text { NO } & \mathbf{1} & \mathbf{0} & \mathbf{1 2} & \mathbf{2 9} & \mathbf{6 3} & \mathbf{1} & \mathbf{3} & \mathbf{2} & \mathbf{1 4} & \mathbf{4 9} & \mathbf{1 7 4}\end{array}$




$\begin{array}{lrrrrrrrrrrr}\text { E+WELL+S } & 0 & 0 & 0 & 1 & 1 & 0 & 0 & 0 & 1 & 1 & 4 \\ \text { S+WELL+E } & 0 & 0 & 5 & 2 & 1 & 0 & 0 & 0 & 2 & 1 & 11 \\ \text { S+WELL+S } & 1 & 0 & 5 & 14 & 3 & 0 & 3 & 4 & 40 & 19 & 89 \\ \text { WELL } & \mathbf{1} & \mathbf{0} & \mathbf{1 0} & \mathbf{1 7} & \mathbf{5} & \mathbf{0} & \mathbf{3} & \mathbf{4} & \mathbf{4 3} & \mathbf{2 1} & \mathbf{1 0 4}\end{array}$

$\begin{array}{llllllllllll}\text { TOTAL } & 2 & 0 & 23 & 58 & 85 & 1 & 6 & 8 & 57 & 115 & 355\end{array}$

\section{Footnotes}

[1] Paper presented at a conference on BAD LANGUAGE held at Copenhagen University 13-14 November, 1998.

[2] Words within parentheses form the gloss primarily of the Swedish parts of the utterances. Stretches of English have usually been left out. The interviewer's words are given within square brackets. References to the identity of the speakers and the position on the tapes have been left out.

[3] Frames including $\varnothing$ indicate that the reaction signal occupies a final position.

[4] Since the reaction signals usually follow immediately upon the interviewer's question, cases where the interviewee's response involves a switch are also included.

\section{References}

AIJMER, KARIN. Forthcoming. Corpus-linguistic aspects of discourse particles: The case of actually. Seminar paper presented at Växjö University, 28 October, 1998.

AUER, J.C.P. 1984. Bilingual conversation. Amsterdam: John Benjamins.

BERGER, V. 1912. Vårt språk. Rock Island, Illinois: Augustana Book Concern.

BRINTON, LAUREL J. 1996. Pragmatic markers in English. Grammaticalization and

discourse functions. Berlin: Mouton de Gruyter.

CLYNE, MICHAEL. 1967. Transference and triggering. The Hague: Nijhoff.

FERNANDEZ, M.M. JOCELYNE. 1994. Les particules énonciatives. Paris: Presses

Universitaires de France.

GUMPERZ, JOHN J. 1982. Discourse strategies. Cambridge: Cambridge University Press.

HALLIDAY, M.A.K. \& RUQAIYA HASAN. 1980. Cohesion in English. London:

Longman.

HASSELMO, NILS. 1970. Code-switching and modes of speaking. In Texas Studies in

Bilingualism. Berlin: de Gruyter.

HASSELMO, NILS. 1974. Amerikasvenska. Lund: Esselte Studium.

HEDBLOM, FOLKE. 1963. Om svenska folkmål i Amerika. In Svenska

Landsmål/Archives des traditions populaires suédoises 1962: 113-157.

KLINTBORG, STAFFAN. 1996. Linkers, fillers, tags and flags - code-switching of conjunctions and conversational signals among American Swedes. In P. Sture Ureland \& Iain Clarkson (eds.) Language contact across the North Atlantic. Tübingen: Max Niemeyer Verlag.

ÖSTMAN, JAN-OLA. 1995. Pragmatic particles twenty years after. In B. Wårwik, S-K. Tanskanen \& R. Hiltunen (eds.) Organization in discourse. Proceedings from the Turku conference. 1995. Anglicana Turkuensia 14: 95-108. Turku: University of Turku.

POPLACK, SHANA. 1980. Sometimes I'll start a sentence in Spanish Y TERMINO EN ESPAÑOL: toward a typology of code-switching. Linguistics 18: 581-618.

QUIRK, RANDOLPH, SIDNEY GREENBAUM, GEOFFREY LEECH \& JAN

SVARTVIK. 1985. A comprehensive grammar of the English language. London: Longman. 
SCHIFFRIN, DEBORAH. 1987. Discourse markers. Cambridge: Cambridge University Press. 